\title{
3 Research Square

\section{Antimicrobials in Chicken Commercial Feeds in Vietnam: A Three-Year Longitudinal Study Before A Nationwide Ban of Growth Promoters}

Juan Carrique-Mas ( $\nabla$ jcarrique-mas@oucru.org )

Oxford University https://orcid.org/0000-0001-9161-8890

Nguyen Van Cuong

University of Oxford

Bach Tuan Kiet

Sub-Department of Animal Health, Dong Thap

Bo Ve Hien

Sub-Department of Animal Health, Dong Thap

\section{Bao Dinh Truong}

University of Oxford

Doan Hoang Phu

University of Oxford

Guy Thwaites

University of Oxford

Marc Choisy

University of Oxford

\section{Research}

Keywords: Antimicrobial Growth Promoters (AGPs), Commercial feeds, AGPs ban, Vietnam, small-scale, Chicken

Posted Date: May 29th, 2020

DOI: https://doi.org/10.21203/rs.3.rs-31003/v1

License: (c) (i) This work is licensed under a Creative Commons Attribution 4.0 International License.

Read Full License 


\section{Abstract}

Background Antimicrobial growth promoters (AGPs) are included in commercial animal feed rations in many low- and middle-income countries. We measured antimicrobial use (AMU) in commercial feed products consumed by 338 small-scale chicken flocks in the Mekong Delta of Vietnam, before a nationwide ban on AGPs which is to be phased in over the coming three years. We reviewed the labels of commercial feeds and calculated amounts of antimicrobial active ingredients (AAls) given to flocks, highlighting those that did not comply with Government regulations.

Results Thirty five of 99 different antimicrobial-containing feed products (35.3\%) included at least one AAl. Eight different AAls (avilamycin, bacitracin, chlortetracycline, colistin, enramycin, flavomycin, oxytetracycline, virginamycin) belonging to 5 classes were identified. Brooding feeds contained antimicrobials the most (51.2\%), followed by grower (34.6\%) and finisher feeds (12.5\%). The average amount of AAls given to flocks per $\mathrm{kg}$ of chicken at consumption time was 84.8 (SEM $\pm 9.3 \mathrm{mg}$ ). Quantitatively, chlortetracycline was consumed most (42.2 mg/kg SEM $\pm 0.34 ; 50.0 \%$ of total use), followed by enramycin (18.4 mg SEM $\pm 0.03,21.8 \%$ ) and bacitracin (16.4 $\mathrm{mg} \mathrm{SEM} \pm 0.20,19.4 \%$ ). Antimicrobials in commercial feeds were more commonly given to flocks in the earlier part of the production cycle. A total of $10(9.3 \%)$ products were not compliant with existing Vietnamese regulation (06/2016/TT-BNNPTNT) either because they included a non-authorised AAI (4), had AAls over the permitted limits (4), or both (2).

Conclusions and recommendation We found a discrepancy between current legislation and the types and quantities of AGPs found in chicken feeds; this may be a challenge in coming years when the full ban is implemented, and would require that the authorities step up monitoring efforts. Results from this study should encourage discussion about policies on AGPs in low- and middle-income countries.

\section{Background}

Antimicrobials are used in veterinary medicine for treating and preventing animal disease. In addition, in many countries antimicrobial growth promoters (AGPs) are added to commercial feed rations to promote growth and productivity (1).

The global annual consumption of antimicrobials intended for animal use has been estimated approximately 63 thousand tonnes. In European Union (EU) countries, all of which have well-developed antimicrobial use (AMU) surveillance systems, antimicrobials intended for animal use represent about $2 / 3$ of total AMU (2). It is believed that excessive use of antimicrobials (including AGPs in feeds) in animal production is a major factor contributing to the global rise in AMR (3-5). The total amounts of antimicrobials intended for animal production are expected to increase in coming years due to intensification of livestock production, mostly in low- and middle-income countries (6).

Since AGPs were discovered more than 60 years ago, they have been used extensively in terrestrial mechanism of action remain unknown (1). Only in recent 
years, some countries have started to implement bans on AGPs or restrictions in their use. In the European Union AGPs have been banned since 2006 (7). In the USA, voluntary phasing out of certain AGPs has been implemented since 2013 (8). In the Asia-Pacific region, several countries have implemented a full ban of AGP in animal feeds in Korea (2011), Australia (2013) (9), Thailand (2015) (10); or restricting certain AGPs in China (2016) (11) and India (2019) (12).

Worldwide annual consumption of poultry meat (2013-2015) stands at 110,280 tonnes, second only to pork (117,005 tonnes). By 2025, chicken production is expected to surpass that of pork production(13). Until recently, AGPs have been extensively included in pig and poultry rations in Vietnam. Extrapolation from a retail survey estimated that in Vietnam $77 \mathrm{mg}$ of AGPs are used to produce $1 \mathrm{~kg}$ of chicken (14). A study of medium-sized chicken farms estimated that chickens consumed $57 \mathrm{mg}$ of AGPs per $\mathrm{kg}$ of chicken produced (15). However the study was based on a small sample of 6 farms.

A 2002 Vietnamese government regulation on animal feeds (54/2002/QĐ-BNN) included the ban of 18 chemicals (including chloramphenicol, metronidazole and nitrofurans) (16). Later (2014), new legislation (28/2014/TT-BNNPTNT) expanded this list to bacitracin, carbadox and olaquidox (17). In May 2016 Vietnam issued Circular 06/2016/TT-BNNPTNT (18) explicitly indicating the list of AAls authorized to be used in commercial feed types as AGPs, as well as the maximum levels allowed in each feed type. According to this regulation, the maximum number of different AAls to be included in each feed was limited to two. In 2018, Vietnam introduced an Animal Law (32/2018/QH14) (19) which included a ban on AGPs in commercial feeds. A further decree (13/2020/ND-CP) (20) established the timeframe for its implementation: critically-important AAls still can be used until the end of 2020, highly important AAls until the end of 2021, important AAls until the end of 2022 and other permitted AAls until the end of 2025.

This study aimed at investigating the types and quantities of AAls in commercial feed in a large representative cohort of small-scale chicken flocks in the Mekong Delta region of Vietnam immediately before the implementation of the new Animal Law. This information complements existing data on antimicrobials administered by farmers (normally mixed in water) (21), providing a comprehensive picture on AMU in small-scale chicken flocks in the region. The situation of AGP in chicken farming is likely to be comparable to other countries in the region yet to implement a ban, as well as should form a baseline in order to confirm future reductions in AMU in animal production in Vietnam.

\section{Results}

\section{Description of commercial feed products}

A total of 99 different commercial feed products were identified. Those products were produced for usage in chicken (85 products, $85.9 \%)$, pig $(12,12.1 \%)$, and duck $(2,2.0 \%)$. Feed products were classified according to their indication (production stage): brooder $(n=40)$, grower $(n=24)$ and finisher $(n=35)$. A total of 35 (35.3\%) contained at least one antimicrobial. All of the 35 antimicrobial-containing feeds were intended for rhirken wee The detailed information on these antimicrobial-containing products is Loading [MathJax]/jax/output/CommonHTML/jax.js

Page 3/15 
available in Supplementary Table 1. Brooder feed products contained AAls the most (51.2\%), followed by grower (34.6\%) and finisher (12.5\%) feeds. All except one product (a brooder feed that contained both chlortetracycline and colistin) contained one AAI. A total of 12 (34\%) products had an imprecise (ambiguous) label, indicating they contained one of 2-4 listed AAls. A total of 8 different AAls belonging to 5 classes were listed in the 35 feed products. The most common AAls listed were enramycin $(18.8 \%$ feeds), followed by bacitracin (16.5\% chicken feeds), chlortetracycline (15.3\%), avilamycin (5.9\%), flavomycin (4.6\%), colistin (3.7\%), virginamycin (2.4\%), and oxytetracycline (1.2\%) (Table 1$)$. A total of 10 (9.3\%) products were not compliant with Regulation 06/2016/TT-BNNPTNT, either because they included a non-authorised AAl (avilamycin, flavomycin, oxytetracycline) $(n=4), A A l / s$ over the permitted limits $(n=$ $4)$, or for both reasons $(n=2)$. 
Table 1

Antimicrobial active ingredients (AAIs) and their concentrations in 85 chicken feed products given to flocks in Dong Thap.

\begin{tabular}{|c|c|c|c|c|c|c|}
\hline \multirow[t]{2}{*}{ AAls } & \multirow[t]{2}{*}{ Class } & \multirow[t]{2}{*}{$\begin{array}{l}\text { Products } \\
(n=85) \\
(\%)\end{array}$} & \multicolumn{3}{|c|}{$\begin{array}{l}\text { AAl mean concentration } \\
\text { (range in } \mathrm{mg} / \mathrm{kg} \text { feed) (No. } \\
\text { products) }\end{array}$} & \multirow[t]{2}{*}{$\begin{array}{l}\text { **Permitted } \\
\text { concentration } \\
\text { (range in } \mathrm{mg} / \mathrm{kg} \\
\text { feed) }\end{array}$} \\
\hline & & & Brooder & Grower & Finisher & \\
\hline Enramycin & Polipeptides & $\begin{array}{l}16 \\
(18.8)\end{array}$ & $\begin{array}{l}{[7.7-} \\
10](7)\end{array}$ & $\begin{array}{l}{[8.2-} \\
10](5)\end{array}$ & $\begin{array}{l}{[11.6-} \\
11.6] \\
(4)\end{array}$ & {$[1-10]$} \\
\hline Bacitracin & Polipeptides & $\begin{array}{l}14 \\
(16.5)\end{array}$ & $\begin{array}{l}{[51.1-} \\
63.1] \\
(8)\end{array}$ & $\begin{array}{l}{[125-} \\
125](1)\end{array}$ & $\begin{array}{l}{[50-60]} \\
(5)\end{array}$ & {$[4-50]$} \\
\hline Chlortetracycline & Tetracyclines & $\begin{array}{l}13 \\
(15.3)\end{array}$ & $\begin{array}{l}{[52.7-} \\
61.1] \\
(9)\end{array}$ & $\begin{array}{l}{[40-50]} \\
(4)\end{array}$ & - & [10-50] \\
\hline Avilamycin & Orthosomycin & $5(5.9)$ & $\begin{array}{l}{[12.5-} \\
12.5] \\
(2)\end{array}$ & $\begin{array}{l}{[15-15]} \\
(1)\end{array}$ & $\begin{array}{l}{[10-10]} \\
(2)\end{array}$ & NA \\
\hline Flavomycin & Other ${ }^{\square}$ & $5(5.9)$ & $\begin{array}{l}{[6-6]} \\
(2)\end{array}$ & $\begin{array}{l}{[2-2]} \\
(1)\end{array}$ & $\begin{array}{l}{[10-10]} \\
(2)\end{array}$ & NA \\
\hline Colistin* & Polipeptides & $4(4.7)$ & $\begin{array}{l}{[70-} \\
136.6] \\
(3)\end{array}$ & - & $\begin{array}{l}{[60-} \\
160](1)\end{array}$ & [2-20] \\
\hline Virginamycin & $\begin{array}{l}\text { Streptogramin } \\
\text { A }\end{array}$ & $2(2.4)$ & $\begin{array}{l}{[5-15]} \\
(1)\end{array}$ & - & $\begin{array}{l}{[5-5]} \\
(1)\end{array}$ & {$[5-15]$} \\
\hline Oxytetracycline & Tetracyclines & $1(1.2)$ & $\begin{array}{l}{[50-50]} \\
(1)\end{array}$ & - & - & NA \\
\hline
\end{tabular}

\section{Flock consumption of AMUs through commercial feed}

All flocks used commercial chicken feed. In addition, pig and duck feeds were given to $12.1 \%$ and $0.6 \%$ flocks, respectively. Each flock had been given a median of 2 [IQR 2-3] different commercial feed products. Flocks received a median of 1 [IQR 1-1] antimicrobial-containing products. Chickens were fed a mean of 84.8 (SEM $\pm 9.3 \mathrm{mg}$ ) [range 71.4-98.2] of AAl/kg over their production cycle. Chickens raised in Thap Muoi and Cao Lanh districts were given 87.7 (Standard Error of the mean, SEM $\pm 14.8 \mathrm{mg} / \mathrm{kg}$ ) [range 76.1-99.3] and 81.7 (SEM $\pm 11.0 \mathrm{mg} / \mathrm{kg}$ ) [range 66.3-97.1], respectively. Overall, the highest magnitude of AMU corresponded to chlortetracycline (42.2 mg SEM \pm 0.34 ), followed by enramycin

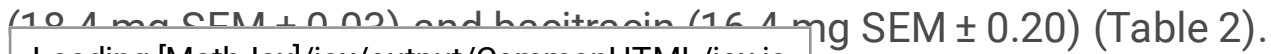


Table 2

AMU in commercial feed among 338 small-scale chicken flocks over 6,041 observation weeks.

\begin{tabular}{|c|c|c|c|}
\hline AAls & $\begin{array}{l}\text { No. flocks } \\
\left(\begin{array}{l}n=338) \\
\%)\end{array}\right.\end{array}$ & $\begin{array}{l}\text { Probability of AMU by week } \\
\text { (mean } \pm \text { SEM) } \\
\text { [lowest-highest] }\end{array}$ & $\begin{array}{l}\text { Total AMU over the production } \\
\text { cycle } \\
\mathrm{mg} / \mathrm{kg} \text { chicken } \\
\text { (mean } \pm \text { SEM) [lowest-highest] (\%) }\end{array}$ \\
\hline Enramycin & $152(45.4)$ & $\begin{array}{l}0.319( \pm 0.004)[0.306- \\
0.333]\end{array}$ & $18.4( \pm 0.03)[17.3-19.5](21.8)$ \\
\hline Chlortetracycline & $73(22.5)$ & $\begin{array}{l}0.134( \pm 0.002)[0.134- \\
0.135\end{array}$ & $42.2( \pm 0.34)[40.6-43.9](50.0)$ \\
\hline Bacitracin & $103(30.5)$ & $\begin{array}{l}0.095( \pm 0.01)[0.080- \\
0.111]\end{array}$ & $16.4( \pm 0.20)[10.5-22.3](19.4)$ \\
\hline Virginamycin & $8(2.9)$ & $\begin{array}{l}0.010( \pm 0.03)[0.005- \\
0.014]\end{array}$ & $0.5( \pm 0.17)[0.1-0.8](0.6)$ \\
\hline Colistin* & $7(2.0)$ & $\begin{array}{l}0.005( \pm 0.03)[0.003- \\
0.008]\end{array}$ & $6.4( \pm 4.21)[2.6-10.3](7.6)$ \\
\hline Avilamycin & $8(2.3)$ & $0.005( \pm \mathrm{NC})[0.0-0.010]$ & $0.3( \pm 0.08)[0.0-0.6](0.4)$ \\
\hline Flavomycin & $8(2.3)$ & $0.005( \pm \mathrm{NC})[0.0-0.010]$ & $0.2( \pm 0.11)[0.0-0.4](0.2)$ \\
\hline Oxytetracyline & $4(1.1)$ & $0.0( \pm \mathrm{NC})[0.0-0.001]$ & $0.07( \pm 0.73)[0.0-0.15](0.1)$ \\
\hline Total & $297(87.8)$ & $\begin{array}{l}0.575( \pm 0.02)[0.529- \\
0.624]\end{array}$ & $84.8( \pm 9.4)[71.4-98.2](100)$ \\
\hline
\end{tabular}

Commercial feed rations were given to flocks in at total of 5,655 of 6,041 (93.6\%) observed weeks. The probability of AMU in flocks decreased with the age of the flock (Fig. 1a). On average, flocks were given AGPs in feed on $57.5 \%(95 \% \mathrm{Cl} 54.5-60.5 \%)$ weeks. Interestingly, a relatively high fraction of brooder products were used in later stages, while some finisher products were also used more in the growing period. Enramycin was used dominantly throughout the production cycle, while colistin was found only in later stages (Fig. 1).

\section{Discussion}

There are very few published data describing and quantifying consumption of AAls (AGPs) in commercial feeds in poultry farming systems in low-and middle income countries (LMICs) (6). Our findings complement existing data on antimicrobials administered to chicken flocks (mainly through water) ( $792 \mathrm{mg} / \mathrm{kg}$ ) in the Mekong Delta region of Vietnam (21). Consumption of in-feed antimicrobials over the life of the flock ( $85 \mathrm{mg} / \mathrm{kg}$ ), represents $~ 10 \%$ of total flock AMU. These figures are consistent with previnus estimates $(77-9.5 \mathrm{ma} / \mathrm{ka})(1415)$ Loading [MathJax]/jax/output/CommonHTML/jax.js 
This study is based on data from an large cohort study aiming at reducing AMU in chicken production in the Mekong Delta of Vietnam (22). The study is representative since the selection of farms was random. Even though our data came from an intervention study, our advice to farmers was focused on reducing AMU as medicine (both prophylaxis and therapeutic), and did not include any advice on feed. We did not find any difference between flocks allocated to the intervention compared with the baseline phase (data not shown).

A major concern is the relatively high number of products that did not comply with Vietnamese regulations. Bacitracin, banned in feed rations in Vietnam since May 2016 (18), was the second most common AAl found. More worryingly, 6/35 (17\%) antimicrobial-containing feeds included AAls in concentrations above those permitted by the Vietnamese authorities. For example, the colistin concentration in all feed products examined was 3-5 times greater than that permitted by the Government. Non-authorised antimicrobials (avilamycin, flavomycin, oxytetracyline) were also found in some chicken feeds. This raises concerns regarding compliance of commercial feed mills with regulations and casts doubts over the effective enforcement of the new decree on animal feeds $(19,20)$. An additional challenge is the ambiguous labelling with regards to AAl in about a third of the rations investigated, posing an additional difficulty to Government authorities for quality control.

Recent studies have reported a high prevalence of colistin resistance encoded by mcr-1 in chicken flocks in the area $(15,23)$. This antimicrobial, classified as highly critically important by WHO $(24)$, was listed in $5 \%$ feeds examined (brooder feeds) and it was estimated that on average, flocks consumed $5 \mathrm{mg} / \mathrm{kg}$ (about $3 \%$ of total in feed AMU). Compared with the reported magnitude of AMU through water administration $(42 \mathrm{mg} / \mathrm{kg}$ ) this is a modest amount. However it is of concern that in our study cohort farms tended to use these feeds towards the end of the production cycle with high drug concentration. This resulted in long elimination profile of antimicrobials, therefore high risk of residues in poultry meat (25).

Quantitatively, chlortetracycline, bacitracin and enramycin were the AAls most consumed through commercial feeds. Tetracyclines were also the most consumed antimicrobial administered through water (21). Tetracyclines is also the class against which resistance among Escherichia coli and non-typhoidal Salmonella strains in the Mekong Delta is highest $(15,23,26-30)$. Bacitracin has been shown to promote resistance among Clostridium perfringens isolates from chickens (31-33). With regards to enramycin, there is little information on its impact on AMR. A Japanese study that investigated Enterococcus faecium isolates from chicken flocks found no evidence of resistance against enramycin (34), although the study presented no enramycin use data.

The inclusion of AGPs in animal feeds and its impact on human health have been the subject of heated debate since the ban of AGP in animal production in Europe $(35,36)$. A major concern in Europe was the widespread use of avoparcin (glycopeptide) as AGP in animal feeds, which resulted in vancomycin resistance among zoonotic Enterococcus faecium bacteria (37). In contrast, studies have indicated that the llce of enramvrin and haritracin ac $\Delta G \mathrm{GP}$ s involves no risk to human health $(38,39)$. The association Loading [MathJax]/jax/output/CommonHTML/jax.js 
between AGPs in animal feeds and human health beyond the scope of this study, and the evidence has been reviewed elsewhere (40). The finding that AAls in feed were consumed during the latter weeks of the production cycle is of concern given the potential for generating residues in chicken meat. A recent survey showed that $8.4 \%$ of chicken meat samples in Vietnam contained antimicrobials residues, with tetracyclines being the most common residue detected (41).

Many researchers have postulated that the withdrawal of AGPs may result in an increase use of antimicrobials for prophylaxis (prevention) or metaphylaxis (mass treatment) (9). In our study, AGPs in chicken feeds represented a small $(10 \%)$ fraction of total AMU and probably have comparatively little impact on disease given the types of antimicrobials included. In low-biosecurity systems, the economic impact and productivity of AGP have been proven to be higher than in optimized-biosecurity production units (9). However, a number of studies recently have been highlighted the overall poor effects of AGPs in poultry productivity $(42,43)$. In the Mekong Delta region of Vietnam, high incidence of infectious disease and losses due to mortality are thought to be the major drivers of productivity. In such cases the potential weight gains are unlikely to be noticeable.

\section{Conclusion}

Our results provide quantitative data on the magnitude of AMU through feed in chicken flocks in the Mekong Delta of Vietnam. It is of concern that a considerable number of feed formulations did not comply with Government regulations. Worryingly, all colistin-containing formulations had a concentration of AAl higher than that permitted by the current regulations. Results from this study should establish a framework for the quality assurance of antimicrobials used in commercial feed rations in Vietnam.

\section{Material And Methods}

\section{Farm selection}

Farm owners in two districts (Cao Lanh, Thap Muoi) within Dong Thap (Mekong Delta, Vietnam) were randomly selected from the official farm census and were contacted by the veterinary authorities. Farmers about to start raising flocks of $\geq 100$ meat chickens that practiced all-in-all out management were recruited, and flocks were followed up longitudinally. A total of 115 farms were recruited (59 in Cao Lanh; 66 in Thap Muoi). Selected farms were part of a longitudinal study aimed at reduce AMU in chicken production through the provision of veterinary advice (22). Owners of selected farms were requested to record in detail the types of commercial feed used and to keep the sacs of all feed products used. A field study team visited farms four times over the production cycle to collect data on commercial feed products used by week. A total of 338 flocks raised in these farms were investigated. Of the 115 farms, 44 completed 1 cycle (38.3.4\%), 25 (21.7\%) 2 cycles, 8 (7.0\%) 3 cycles, 11 (9.6\%) 4 cycles, 12 (10.4\%) 5 cycles, and 15 (13.0\%) more than 5 cycles. The median flock size at restocking was 303 [IQR 200-500]. A total of 6,041 weeks of data were collected. The median duration of one production cycle was 19 [IQR d from October 2016 to Oct 2019. 


\section{AAls in commercial feed products}

All commercial feed products containing an antimicrobial active ingredient (AAl) were singled out after reviewing their label. lonophores (mostly aimed at controlling coccidial infection) were excluded. AAls were described by: (1) target species (duck, chicken or pig); (2) indication by stage of production (brooder, grower or finisher); and (3) type of formulation (crumbs, mash or pellets). From each feed product, we described the AAls contained, its concentration (expressed in $\mathrm{mg} / \mathrm{kg}$ product). AAls were classified based on the OIE list of antimicrobial agents (44) and any antimicrobials regarded as critically important by WHO were highlighted (24). We excluded ionophores since it is thought that these substances, commonly used as coccidiostats, do not have any link with AMR or against antimicrobials commonly used to treat human or animal bacterial disease (45). We identified those feed products containing antimicrobials at concentrations not permitted under Vietnamese legislation (18).

\section{Data analyses}

We calculated AMU consumption in feed by week by relating the amounts of AAI $(\mathrm{mg})$ to the weight of birds at the time of consumption (standard weight of the flock) $(\mathrm{kg})(\mathrm{mg} / \mathrm{kg}$ live chicken) for all weeks $(n)$ over the flock's life duration (Expression 1).

$\mathrm{mg} / \mathrm{kg}$ chicken at time of consumption $=\sum_{k=1}^{n} \frac{\text { AAIused }(\mathrm{mg}) \text { inweekk }}{\text { Standardweightoftheflock }(\mathrm{kg}) \text { atweekk }}$

Weekly consumption of AAls in feed was calculated by multiplying the weekly feed consumption by the AAls concentration indicated in that feed. The feed consumption was estimated from published data related to native Vietnamese layer pullets, where $443 \mathrm{~g}$ of feed were consumed by $1 \mathrm{~kg}$ of live chicken per week (46). The denominator (total weight of the flock at week $k$ ) was calculated from the number of chickens present in the flock multiplied by an estimated (standard) weight. The latter was based on weekly data from 10 randomly selected chickens from 11 representative flocks, from week 1 until week 22 of their production cycle (21).

The concentration (strength) of AAl in each feed product was obtained from its label. However information in a number of feed products contained uncertain information in their labels, concerning the identity of the AAI and the amounts included. For feed products with AAl content ambiguously labeled (i.e. indicating inclusion of one of $>1$ listed AAls), the amount of each AAls was calculated by assigning each antimicrobial a probability corresponding being included (probability $=1$ ), and not being included (probability $=0$ ). For products indicating their AAls concentration as a range, lowest and highest estimates were calculated for each antimicrobial. The amounts of each AAls were summarized in each flock by AAl and by week. The total amounts of each AAI were aggregated to calculate total consumption by flock, including the estimation of a lower and upper limit from the above calculations.

\section{Declarations}




\section{Ethical approval and consent to participate}

This study was granted ethics approval by the Oxford Tropical Research Ethics Committee (OXTREC) (Ref. 5121/16) and by the local authorities (People's Committed of Dong Thap province). All participating farmers consented to the study.

\section{Consent for publication}

Not applicable.

\section{Availability of supporting data}

All data generated or analysed during this study are included in this published article and in its supplementary information file.

\section{Competing interests}

The authors declare no competing interests.

\section{Funding}

The current study was funded by the Wellcome Trust through an Intermediate Clinical Fellowship awarded to Dr. Juan J. Carrique-Mas (Grant Reference Number 110085/Z/15/Z).

\section{Authors' contributions}

NVC, BVH and JCM conceived and designed the study. BTK, DHP and NVC carried out data collection; NVC, MC and JCM performed data analyses; BTK, BDT contributed to data entry, NVC, BDT, DHP, JCM and GT contributed to writing up and editing. All authors read and approved the final manuscript.

\section{Acknowledgments}

We are grateful to all participating farmers and veterinary drug shop owners. We thank staff at SDAH-DT for logistic support.

\section{References}


1. Dibner JJ, Richards JD. Antibiotic growth promoters in agriculture: history and mode of action. Poult Sci. 2005;84(4):634-43.

2. ECDC/EFSA/EMA Second joint report on the integrated analysis of the consumption of antimicrobial agents and occurrence of antimicrobial resistance in bacteria from humans and food-producing animals. EFSA Journal. 2017.

3. Landers TF, Cohen B, Wittum TE, Larson EL. A review of antibiotic use in food animals: perspective, policy, and potential. Public health reports. 2012;127(1):4-22.

4. Marshall BM, Levy SB. Food animals and antimicrobials: impacts on human health. Clin Microbiol Rev. 2011;24(4):718-33.

5. Chantziaras I, Boyen F, Callens B, Dewulf J. Correlation between veterinary antimicrobial use and antimicrobial resistance in food-producing animals: a report on seven countries. J Antimicrob Chemother. 2014;69(3):827-34.

6. Cuong NV, Padungtod P, Thwaites G, Carrique-Mas JJ. Antimicrobial Usage in Animal Production: A Review of the Literature with a Focus on Low- and Middle-Income Countries. Antibiotics (Basel). 2018;7(3).

7. Castanon Jl. History of the use of antibiotic as growth promoters in European poultry feeds. Poult Sci. 2007;86(11):2466-71.

8. FDA. CVM GFI \#213 New animal drugs and new animal drug combination products administered in or on medicated feed or drinking water of food-producing animals: recommendations for drug sponsors for voluntarily aligning product use conditions with GFI \#209 2013. Available at: https://www.fda.gov/regulatory-information/search-fda-guidance-documents/cvm-gfi-213-newanimal-drugs-and-new-animal-drug-combination-products-administered-or-medicated-feed.

9. Laxminarayan R, T. Van Boeckel and A. Teillant. The economic costs of withdrawing antimicrobial growth promoters from the livestock sector: No. 78, OECD; 2015. Available at: https://www.oecdilibrary.org/agriculture-and-food/the-economic-costs-of-withdrawing-anti-microbial-use-in-thelivestock-sector_5js64kst5wvl-en.

10. Thamlikitkul V, Rattanaumpawan P, Boonyasiri A, Pumsuwan V, Judaeng T, Tiengrim S, et al. Thailand Antimicrobial Resistance Containment and Prevention Program. J Glob Antimicrob Resist. 2015;3(4):290-4.

11. Walsh TR, Wu Y. China bans colistin as a feed additive for animals. Lancet Infect Dis. 2016;16(10):1102-3.

12. MOH-FW. Prohibition of colistin for food producing animals, poultry, aqua farming and animal feed supplements under Sec.26A. 2109.

13. OECD-FAO. OECD-FAO Agricultural Outlook 2016-2025 2016. Available at: https://www.oecdilibrary.org/agriculture-and-food/oecd-fao-agricultural-outlook-2016_agr_outlook-2016-en.

14. Van Cuong N, Nhung NT, Nghia NH, Mai Hoa NT, Trung NV, Thwaites G, et al. Antimicrobial consumption in medicated feeds in Vietnamese pig and poultry production. Ecohealth. 
15. Nguyen NT, Nguyen HM, Nguyen CV, Nguyen TV, Nguyen MT, Thai HQ, et al. Use of colistin and other critical antimicrobials on pig and chicken farms in southern vietnam and its association with resistance in commensal Escherichia coli bacteria. Appl Environ Microbiol. 2016;82(13):3727-35.

16. MARD. Decision 54/2002/QĐ-BNN Prohibit of manufacture, import, circulation, sale and use of antibiotics and chemicals in animal feeds 2002. Available at: https://thuvienphapluat.vn/vanban/thuong-mai/quyet-dinh-54-2002-qd-bnn-cam-san-xuat-nhap-khau-luu-thong-va-su-dung-khangsinh-hoa-chat-trong-san-xuat-va-kinh-doanh-thuc-an-chan-nuoi-49687.aspx.

17. MARD. Circular 28/2014/TT-BNNPTNT Prohibit of manufacture, import, circulation, sale and use of antibiotics and chemicals in animal feeds 2014 [Available from: https://thuvienphapluat.vn/vanban/thuong-mai/quyet-dinh-54-2002-qd-bnn-cam-san-xuat-nhap-khau-luu-thong-va-su-dung-khangsinh-hoa-chat-trong-san-xuat-va-kinh-doanh-thuc-an-chan-nuoi-49687.aspx.

18. MARD. Circular 28/2014/TT-BNN. Promulgation of the list of antibiotics and concentration for usage as AGP in livestock production in Vietnam 2016. Available at: https://luatvietnam.vn/nongnghiep/thong-tu-06-2016-tt-bnnptnt-bo-nong-nghiep-va-phat-trien-nong-thon-105650-d1.html.

19. Anon. Vietnam animal husbandry legislation (Law No. 32/2018/QH14). 2018.

20. Anon. Decree on detail guidelines for launching animal husbandry law (13/2020/ND-CP) 2020. Available at: https://thuvienphapluat.vn/van-ban/linh-vuc-khac/Nghi-dinh-13-2020-ND-CP-huongdan-Luat-Chan-nuoi-433295.aspx.

21. Cuong NV, Phu DH, Van NTB, Dinh Truong B, Kiet BT, Hien BV, et al. High-resolution monitoring of antimicrobial consumption in Vietnamese small-scale chicken farms highlights discrepancies between study metrics. Front Vet Sci. 2019;6:174.

22. Carrique-Mas JJ, Rushton J. Integrated Interventions to Tackle Antimicrobial Usage in Animal Production Systems: The ViParc Project in Vietnam. Front Microbiol. 2017;8:1062.

23. Trung NV, Matamoros S, Carrique-Mas JJ, Nghia NH, Nhung NT, Chieu TT, et al. Zoonotic transmission of mcr-1 colistin resistance gene from small-scale poultry farms, Vietnam. Emerg Infect Dis. 2017;23(3):529-32.

24. WHO. Critically important antimicrobials for human medicine, 6th revision 2019. Available at: https://www.who.int/foodsafety/publications/antimicrobials-sixth/en/.

25. Patel T, Marmulak T, Gehring R, Pitesky M, Clapham MO, Tell LA. Drug residues in poultry meat: A literature review of commonly used veterinary antibacterials and anthelmintics used in poultry. $\mathrm{J}$ Vet Pharmacol Ther. 2018;41(6):761-89.

26. Nguyen VT, Carrique-Mas JJ, Ngo TH, Ho HM, Ha TT, Campbell Jl, et al. Prevalence and risk factors for carriage of antimicrobial-resistant Escherichia coli on household and small-scale chicken farms in the Mekong Delta of Vietnam. J Antimicrob Chemother. 2015;70(7):2144-52.

27. Nhung NT, Cuong NV, Campbell J, Hoa NT, Bryant JE, Truc VN, et al. High levels of antimicrobial resistance among Escherichia coli isolates from livestock farms and synanthropic rats and shrews in the Mekong Delta of Vietnam. Appl Environ Microbiol. 2015;81(3):812-20. 
28. Trung NV, Carrique-Mas JJ, Nghia NH, Tu LT, Mai HH, Tuyen HT, et al. Non-typhoidal Salmonella colonization in chickens and humans in the Mekong Delta of Vietnam. Zoonoses Public Health. 2017;64(2):94-9.

29. Tu LT, Hoang NV, Cuong NV, Campbell J, Bryant JE, Hoa NT, et al. High levels of contamination and antimicrobial-resistant non-typhoidal Salmonella serovars on pig and poultry farms in the Mekong Delta of Vietnam. Epidemiol Infect. 2015;143(14):3074-86.

30. Yen NTP, Nhung NT, Van NTB, Cuong NV, Tien Chau LT, Trinh HN, et al. Antimicrobial residues, nontyphoidal Salmonella, Vibrio spp. and associated microbiological hazards in retail shrimps purchased in Ho Chi Minh city (Vietnam). Food Control. 2020;107:106756.

31. Silva RO, Salvarani FM, Assis RA, Martins NR, Pires PS, Lobato FC. Antimicrobial susceptibility of Clostridium perfringens strains isolated from broiler chickens. Braz J Microbiol. 2009;40(2):262-4.

32. Slavic D, Boerlin P, Fabri M, Klotins KC, Zoethout JK, Weir PE, et al. Antimicrobial susceptibility of Clostridium perfringens isolates of bovine, chicken, porcine, and turkey origin from Ontario. Can J Vet Res. 2011;75(2):89-97.

33. Mwangi S, Timmons J, Fitz-Coy S, Parveen S. Characterization of Clostridium perfringens recovered from broiler chicken affected by necrotic enteritis. Poult Sci. 2019;98(1):128-35.

34. Yoshimura H, Ishimaru M, Endoh YS, Kojima A. Antimicrobial susceptibilities of Enterococci isolated from faeces of broiler and layer chickens. Lett Appl Microbiol. 2000;31(6):427-32.

35. Collignon P. Antibiotic growth promoters. J Antimicrob Chemother. 2004;54(1):272; Author reply 6-8.

36. Phillips I, Casewell M, Cox T, De Groot B, Friis C, Jones R, et al. Does the use of antibiotics in food animals pose a risk to human health? A critical review of published data. J Antimicrob Chemother. 2004;53(1):28-52.

37. Wegener HC, Aarestrup FM, Jensen LB, Hammerum AM, Bager F. Use of antimicrobial growth promoters in food animals and Enterococcus faecium resistance to therapeutic antimicrobial drugs in Europe. Emerg Infect Dis. 1999;5(3):329-35.

38. Phillips I. The use of bacitracin as a growth promoter in animals produces no risk to human health. $J$ Antimicrob Chemother. 1999;44(6):725-8.

39. Anon. Food Safety Commission of Japan. Enramycin used for food producing animals: Risk of antimicrobial-resistant bacteria. 2015 Available at: https://www.jstage.jst.go.jp/article/foodsafetyfscj/3/1/3_2015004/_pdf/-char/en.

40. Hoelzer K, Wong N, Thomas J, Talkington K, Jungman E, Coukell A. Antimicrobial drug use in foodproducing animals and associated human health risks: what, and how strong, is the evidence? BMC Vet Res. 2017;13(1):211.

41. Nhung NT, Van NTB, Cuong NV, Duong TTQ, Nhat TT, Hang TTT, et al. Antimicrobial residues and resistance against critically important antimicrobials in non-typhoidal Salmonella from meat sold at wet markets and supermarkets in Vietnam. Int J Food Microbiol. 2018;266:301-9.

42. Hamid H, Zhao LH, Ma GY, Li WX, Shi HQ, Zhang JY, et al. Evaluation of the overall impact of Loading [MathJax]/jax/output/CommonHTML/jax.js health and productivity during the medication and withdrawal 
period. Poult Sci. 2019;98(9):3685-94.

43. Kumar S, Chen C, Indugu N, Werlang GO, Singh M, Kim WK, et al. Effect of antibiotic withdrawal in feed on chicken gut microbial dynamics, immunity, growth performance and prevalence of foodborne pathogens. PLoS One. 2018;13(2):e0192450.

44. Anon. OIE list of antimicrobial agents of veterinary importance 2015.

45. Anon. MSD Veterinary Manual 2019. Available at:

https://www.msdvetmanual.com/pharmacology/antibacterial-agents/penicillins.

46. Anon. Gà hậu bị và gà đẻ cao sản 2019. Available at: https://www.deheus.com.vn/san-pham/thucan-cho-ga/ga-de.

\section{Figures}

a)

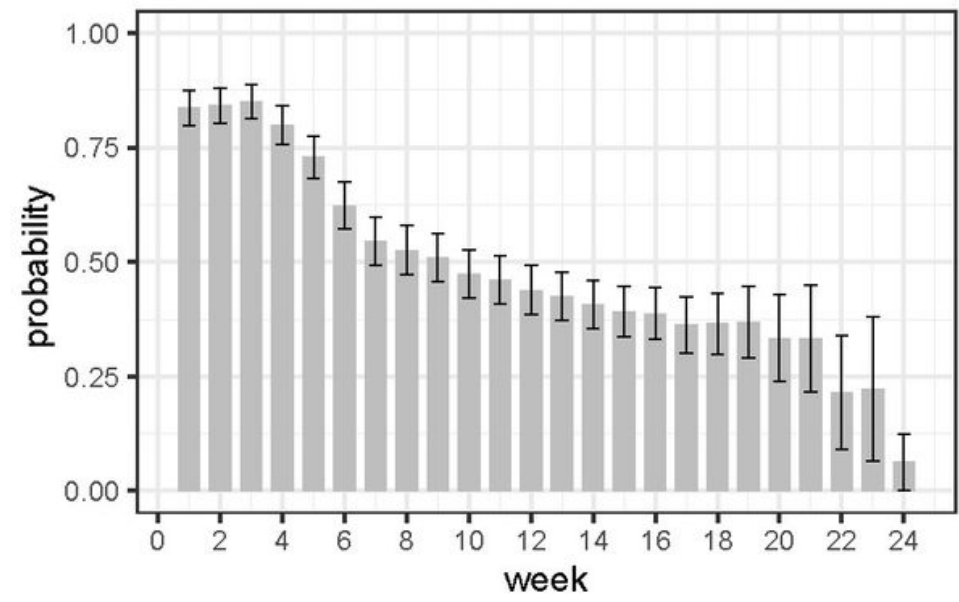

c)

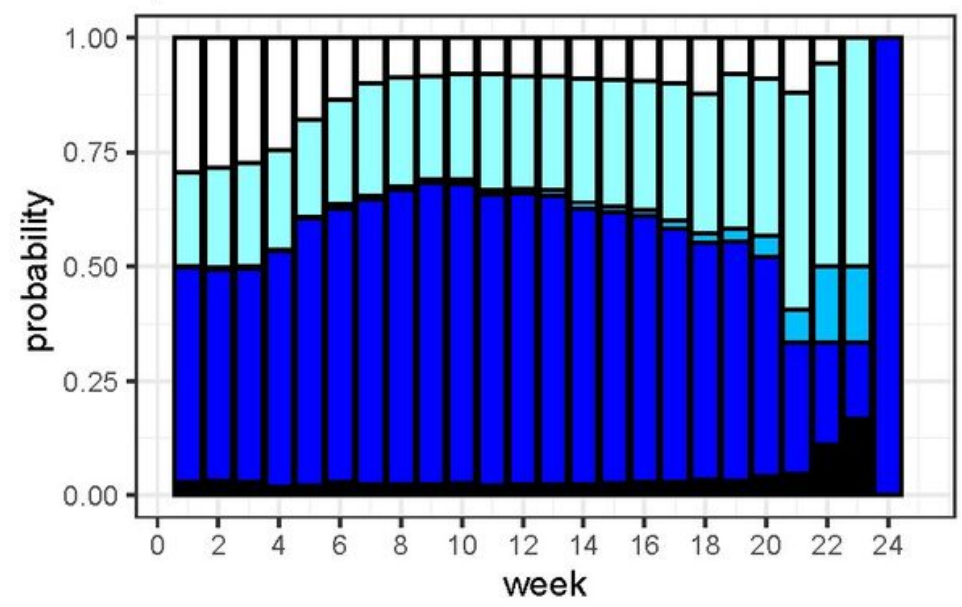

b)
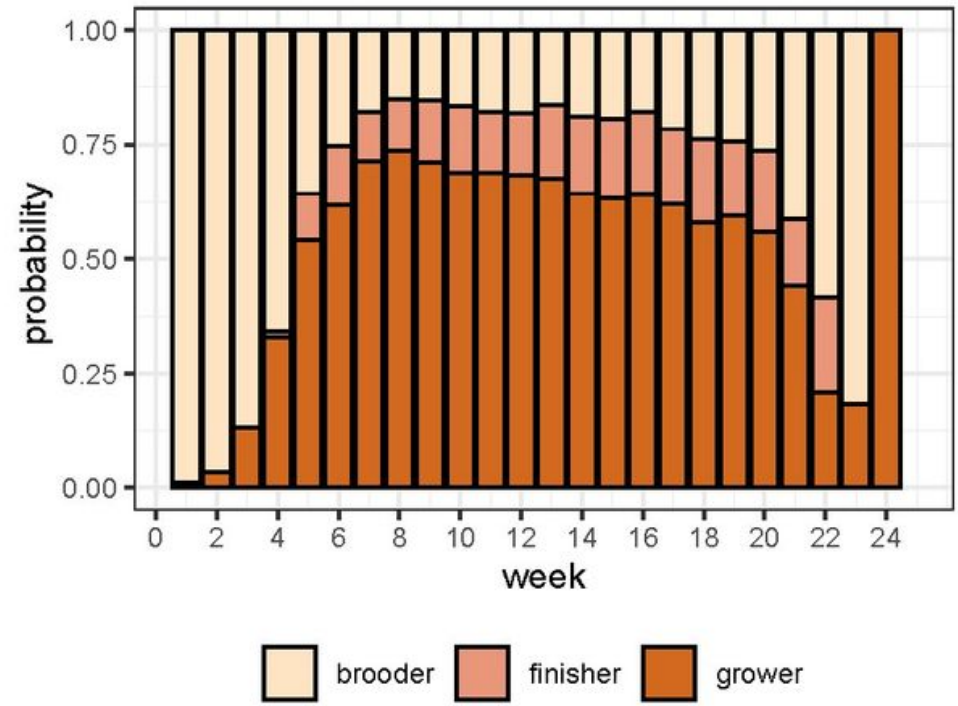

\section{Figure 1}

(a) Probability of consumption of AAls in chicken feeds by week among study flocks; (b) Weekly distribution of types of feed (production stage) consumed by flocks; (c) Weekly distribution of AAls Loading [MathJax]/jax/output/CommonHTML/jax.js imal feeds. 


\section{Supplementary Files}

This is a list of supplementary files associated with this preprint. Click to download.

- SupplementaryTable1.docx

- Weeklydata.xlsx 